\title{
Chemical composition, organic matter digestibility and gas production of nine legume grains
}

\author{
José Manuel Fernandes Abreu *, Arminda Martins Bruno-Soares
}

Instituto Superior de Agronomia Tapada da Ajuda, 1399 Lisboa Codex, Portugal

Accepted 26 March 1997

\begin{abstract}
Nine legume grains (Pisum sativum, Cicer arietinum, Vicia sativa, Vicia faba, Lathyrus ochrus, Lathyrus cícera, Lupinus angustifolius and Lupinus luteus) wcre studied with respect to their chemical composition, organic matter digestibility (OMD) and digestible energy (DE) using rams in metabolic cages. Gas production by grains was evaluated using rumen inoculum. The majority of these legume grains showed values of: crude protein (CP) 21 to $24 \%$, ether extract (EE) -1.5 to $5 \%$, neutral detergent fibre (NDF) -15 to $22 \%$, acid detergent fibre (ADF) -6 to $13 \%$, starch - 30 to $40 \%$, OMD - 90 to $92 \%$, DE -16 to $17 \mathrm{MJ} \mathrm{kg}^{-1}$ dry matter (DM) and gas production ( $48 \mathrm{~h}$ ) of 110 to $145 \mathrm{ml} \mathrm{g}^{-1} \mathrm{DM}$. Lupinus however showed much higher values of $\mathrm{CP}(29.1 \%$ and $34.4 \%)$, NDF (26.9\% and $28.6 \%), \operatorname{ADF}(22.9 \%$ and $24.6 \%)$, EE (5.4\% and $7.2 \%)$ and lower values of starch about $0.8 \%$, OMD $(83.6 \%$ and $86.0 \%)$ and gas production $(95.9$ and $\left.104.6 \mathrm{ml} \mathrm{g}^{-1} \mathrm{DM}\right)$. Gas production $(48 \mathrm{~h})$ was negatively correlated to $\mathrm{CP}(r=-0.74$; $P<0.05)$, NDF $(r=-0.93 ; P<0.001)$, ADF $(r=-0.78 ; P<0.01)$, positively with starch $(r=0.70 ; P<0.05)$ and positively with OMD $(r=0.68 ; P<0.05)$. Gas production in this type of feed was not shown to be a good criterion for assessing their OMD. C 1998 Elsevier Science B.V.
\end{abstract}

Keywords: Legume grains; Chemical composition; Nutritive value; Gas production; Ruminants

\section{Introduction}

Mediterranean legume grains have a considerable role as protein suppliers in animal diets.

${ }^{*}$ Corresponding author. Tel.: +351-1-3638161; fax: +351-1-3635031. 
However, since the late 1960 s, their importance has been reduced due mainly to the use of oleaginous meals, mostly soybean which have been available at competitive prices.

As a consequence, an important reduction in legume grain cultivation was noted (Cubero, 1983). This was due to a lack of genetic and technological improvement. This seems to have happened also in other countries in South Europe (Duffus and Duffus, 1991).

In order to reduce the dependence of Europe in imported legume grains as protein sources for animals, the EU has initiated some production incentive policies (Todorov, 1988; Chominot, 1992).

Within the few researchers who have studied the nutritive value of mediterranean legume grains, special reference must be made to the work of Wiseman and Cole (1988) with pigs and Castanon and Perez-Lanzac (1990) with layer hens, and of Hadjipanayiotou et al. (1985) with sheep, pointed to the possibility of using these grains in animal diets, although in limited amounts.

In this study we used varieties of legume plants well adapted to the conditions of our country and considered of interest for animal nutrition for feeding grazing during the summer months (when in our conditions pasture gets scarce and poor).

The aim of the work presented was: (i) to evaluate the nutritive value of nine legume grains, growing in identical conditions, using rams in metabolic cages and (ii) to compare two different approaches, chemical composition and gas production (Menke et al., 1979), in estimating the nutritive value.

\section{Material and methods}

\subsection{Feeds and analysis}

Nine legume grains (selected lines) were studied: 1. (Ps) - Pea (Pisum sativum L.) cv. Gp 950; 2. (Caw) - White chick pea (Cicer arietinum L.) cv. Ch K283; 3. (Cab) - Black chick pea (Cicer arietinum L.) cv. Ch D 323; 4. (Vs) - Vetch (Vicia sativa L.) cv. do Caia; 5. (Vf) - Horse bean (Vicia faba L. vsr. minor) cv. Beja; 6. (Lo) -Cyprus vetch (Lathyrus ochrus (L.) DC.) cv. LAT 8290; 7. (Lc) - Red vetchling (Lathyrus cicera L.) cv. da Gramicha; 8. ( La) - Blue lupin (Lupinus angustifolius L.) cv. Ilyarrie e 9. $(L l)$ - Yellow lupin (Lupinus luteus L.) cv. Cardiga.

The grains were obtained in the National Plant Breeding Station in Elvas (south of Portugal), in dry farming conditions ( $600 \mathrm{~mm}$ rainfall) and clay soils. The selected lines were obtained in the same field and technological (screening, calibration, etc.) conditions. Representative amounts of each variety were taken. Chemical composition were assessed using two samples from each legume grain and the results shown are the corresponding means. They were analysed for ash, crude protein (CP), ether extract (EE) and crude fibre (CF) according to Association of Official Analytical Chemists (1980), water insoluble cell walls (WICW) according to Carré and Brillouet (1989) and neutral detergent fibre (NDF), acid detergent fibre (ADF) and acid detergent lignin (ADL) 
according to Robertson and Van Soest (1981). The starch content was determined according to Thivend et al. (1965), the total sugars according to NP (1986) and gross energy (GE) in a calorimeter bomb (Parr 1261).

\subsection{In vivo digestibility}

The grains were mixed with barley straw and given to caged rams. The organic matter digestibility (OMD) and gross energy digestibility (GED) of each mixture (diet) were determined. OMD and GED of each legume grain were calculated by the indirect method as described hy Lloyd et al. (1978). The digestibilities of the barley straw ( $\mathrm{OMD}=44.0 \%$; $\mathrm{GED}=45.1 \%$ ) were previously determined using eight caged rams. The straw was chopped, supplemented with nitrogen and mineral and given to the rams.

Grains were broken using a mill of $5 \mathrm{~mm}$ round holes - so as to obtain practically no particles smaller than $1 \mathrm{~mm}$.

Three groups of four Merino rams each time, each legume grain to each group, $50 \mathrm{~kg}$ average liveweight, in metabolic cages were used. Each animal received $200 \mathrm{~g}$ of chopped barley straw and $600 \mathrm{~g}$ of a particular legume grain by day in two identical meals, at 0830 and $1630 \mathrm{~h}$.

Animals were restricted fed. The total absence of residues was checked. Animals were kept in identical environmental conditions in all trials.

The amounts of legume grains that were eaten by the animals in each trial did not apparently cause any troubles in their health.

The body condition (Jefferies, 1961; Frutos et al., 1995) of the rams stayed practically at 3.5 during the trials. The rams liveweights stayed practically at the same level during each trial period ( 25 days).

The OMD and GED of each diet were calculated per day and per animal, during 10-day data collecting periods. A 15-day period of adaptation was used.

Faeces were totally collected every $24 \mathrm{~h}$ during the trial period, dried in a forced ventilation oven at $65^{\circ} \mathrm{C}$, and milled $(1 \mathrm{~mm}$ mesh) for analyses.

GE, dry matter (DM) and ash were determined in grains, faeces and barley straw in each period; faeces determination were carried out per animal and collecting period.

\subsection{Gas production}

Three rumen cannulated rams (55 kg average liveweight) were used, each receiving $700 \mathrm{~g}$ of (Avena sativa - Vicia sativa) hay and $300 \mathrm{~g}$ of a concentrate (50\% barley grain, $25 \%$ soybean meal, $21 \%$ soybean hulls and $4 \%$ minerals and vitamins) meal in two identical meals, at 0830 and $1630 \mathrm{~h}$. The chemical composition of the feeds was: hay $\mathrm{CP}=8.7 \%$; $\mathrm{ADF}=44.1 \%$; concentrate $\mathrm{CP}=32.6 \%$; $\mathrm{ADF}=20.0 \%$.

The gas volume produced by the grains was evaluated using the Menke technique (Menke et al., 1979).

The grains were milled to pass a $1 \mathrm{~mm}$ mesh and a sample of about $200 \mathrm{mg}$ of DM was used. The volume of gas was measured at $2,4,6,8,12,24,30$ and $48 \mathrm{~h}$ after initiation of incubation. There were six measurements for each sampling period ( 3 tubes per hour of collection $\times 2$ trial replicates). 


\subsection{Statistic}

Data on OMD and GED and data on gas volume produced in 24, 30 and $48 \mathrm{~h}$ were subjected respectively to ANOVA II and ANOVA I tests, using the Duncan test for comparison of averages (Duncan, 1955).

Among the variables studied (chemical composition and OMD), a stepwise analysis was used to determine which among them best explained the variations in gas production.

Multiple linear regression analysis were used to verify the variable that best explains the variations in $\mathrm{OMD}$.

\section{Results}

\subsection{Chemical composition and gross energy}

Table 1 gives the chemical composition and GE of the proteaginous grains.

Lupinus excepted the CP of most grains showed values between 21 and 24\%. The high values of $\mathrm{CP}$, characteristic of lupinus (about $30 \%$ or higher) may be partially due to the lower starch level (Elkowicz and Sosulski, 1982); the observed values were, as a rule, slightly lower than those given in the literature (MAPA, 1984; INRA, 1988, Castanon and Perez-Lanzac, 1990). The varieties used (Wiseman and Cole, 1988), the sites and growth conditions (Holl and Vose, 1980), may be responsible for the observed results.

The higher values of EE were found in (Caw), $(\mathrm{Cab})$ and in lupinus, especially in ( $L a)$, with $7.2 \%$.

The values of cell walls, represented by $\mathrm{NDF}$, varied between $10.9 \%$ in $(\mathrm{Caw})$ to $28.6 \%$ in $(L l)$, and the corresponding values of ADF were $5.8 \%$ and $24.6 \%$. The WICW varied between $11.0 \%$ and $38.0 \%$

As to starch, most proteaginous showed values betwecn 38 and $46 \%$ except the lupinus which gave the lowest values of about 0.8\%. INRA (1984) and Abreu et al.

Table 1

Chemical composition of legume grains (\% DM)

\begin{tabular}{lrrrrrrrrrr}
\hline Legume grains & Ash & CP & EE & CF & NDF & ADF & ADL & WICW & Starch & Total sugars $^{\text {a }}$ \\
\hline Pea & 3.3 & 21.0 & 1.7 & 7.2 & 14.6 & 8.1 & 1.1 & 17.1 & 45.3 & 3.7 \\
White chick pea & 3.0 & 21.5 & 5.2 & 3.9 & 10.9 & 5.8 & 1.3 & 11.0 & 46.0 & 2.4 \\
Black chick pea & 2.7 & 20.5 & 4.3 & 9.1 & 16.9 & 12.1 & 2.2 & 19.2 & 38.2 & 1.3 \\
Vetch & 3.4 & 23.0 & 1.9 & 5.0 & 21.7 & 7.5 & 0.9 & 13.5 & 43.5 & 1.7 \\
Cyprus vetch & 3.5 & 20.9 & 1.5 & 7.7 & 20.8 & 10.9 & 0.5 & 16.8 & 38.3 & 2.3 \\
Red vetchling & 2.9 & 21.7 & 1.4 & 7.3 & 22.1 & 10.7 & 0.6 & 16.9 & 44.2 & 1.5 \\
Horse bean & 3.8 & 23.7 & 1.4 & 10.0 & 20.2 & 13.1 & 2.4 & 17.2 & 40.0 & 1.9 \\
Blue lupin & 2.6 & 29.1 & 7.2 & 16.1 & 26.9 & 22.9 & 2.8 & 38.0 & 0.8 & 4.5 \\
Yellow lupin & 3.6 & 34.4 & 5.4 & 20.2 & 28.6 & 24.6 & 2.8 & 35.3 & 0.7 & 4.1 \\
\hline
\end{tabular}

\footnotetext{
${ }^{a}$ Express as saccharose.
} 
Table 2

Gross encrgy (GE), organic matter digestibility (OMD) and digestible energy (DE) of legume grains

\begin{tabular}{lccc}
\hline Legume grains & $\mathrm{GE}\left(\mathrm{MJ} \mathrm{kg}^{-1} \mathrm{DM}\right)$ & $\mathrm{OMD}(\%)$ & $\mathrm{DE}\left(\mathrm{MJ} \mathrm{kg}^{-1} \mathrm{DM}\right)$ \\
\hline Pea & 18.4 & $91.1 \mathrm{a}$ & $16.5 \mathrm{ab}$ \\
White chick pea & 19.3 & $92.1 \mathrm{a}$ & $17.6 \mathrm{a}$ \\
Black chick pea & 19.0 & $90.2 \mathrm{a}$ & $16.9 \mathrm{ab}$ \\
Vetch & 18.3 & $90.5 \mathrm{a}$ & $16.3 \mathrm{ab}$ \\
Cyprus vetch & 18.0 & $91.5 \mathrm{a}$ & $16.1 \mathrm{~b}$ \\
Red vetchling & 18.4 & $90.0 \mathrm{a}$ & $16.2 \mathrm{ab}$ \\
Horse bean & 18.1 & $91.7 \mathrm{a}$ & $16.3 \mathrm{ab}$ \\
Blue lupin & 20.1 & $86.0 \mathrm{~b}$ & $16.5 \mathrm{ab}$ \\
Yellow lupin & 20.0 & $83.6 \mathrm{~b}$ & $16.9 \mathrm{ab}$ \\
\hline
\end{tabular}

Values in the same columns followed by different letters are significantly different $(P<0.05)$.

(1992) showed starch values (acid hydrolysis) of around $42 \%$ for $(P s)$ and $(L c)$, respectively. In turn Daveby and Aman (1993) have found values for ( $V f$ ) between 40 and $45 \%$.

The soluble sugars ranged between 1.3 and $4.5 \%$, the lower value corresponding to $(\mathrm{Cab})$ and the higher to $(\mathrm{La})$. Values of the order of $1.5 \%$ to $2.2 \%$ were observed by Abreu et al. (1992) and INRA (1984) for the grains $(L c)$ and $(P s)$, respectively.

GE varied between 18.0 and $20.1 \mathrm{MJ} \mathrm{kg}^{-1} \mathrm{DM}$, lupinus showing the highest values due, probably, to their higher contents of EE.

\subsection{Digestibilities and digestible energy}

Table 2 gives in vivo $\mathrm{OMD}$ and digestible energy (DE) of legume grains. OMD values ranged between 90 and $92 \%$. Exceptions were the lupinus whose values $(83.6 \%$ and $86.0 \%$ ) were significantly lower.

Hadjipanayiotou et al. (1985) obtained slightly lower values than ours for ( Lo), (Vf) and ( $\mathrm{Caw}$ ), probably due to the higher feeding levels adopted. Values in the order of $90 \%$ and $87 \%$ for $(P s)$ and $\left(V_{s}\right)$ were referred by INRA (1988).

Table 3

Gas production for different legume grains ( $\left.\mathrm{ml} \mathrm{g}^{-1} \mathrm{DM}\right)$

\begin{tabular}{lllllllll}
\hline Legume grains & \multicolumn{7}{l}{ Incubation time $(\mathrm{h})$} \\
\cline { 2 - 9 } & 2 & 4 & 6 & 8 & 12 & 24 & 30 & 48 \\
\hline Pea & 22.8 & 28.0 & 47.0 & 63.4 & 102.2 & 135.9 & 142.3 & $146.7 \mathrm{a}$ \\
White chick pea & 16.8 & 22.6 & 36.6 & 61.0 & 102.2 & 131.2 & 135.7 & $139.6 \mathrm{ab}$ \\
Black chick pea & 15.6 & 22.0 & 37.5 & 56.0 & 94.6 & 118.3 & 126.0 & $131.3 \mathrm{abc}$ \\
Vetch & 23.8 & 31.2 & 35.9 & 49.8 & 72.6 & 113.9 & 119.0 & $119.9 \mathrm{bcd}$ \\
Cyprus vetch & 24.0 & 33.5 & 36.5 & 51.0 & 66.0 & 104.5 & 109.8 & $115.9 \mathrm{cde}$ \\
Red vetchling & 24.0 & 34.4 & 36.9 & 49.8 & 73.1 & 106.8 & 109.7 & $112.0 \mathrm{cde}$ \\
Horse bean & 19.8 & 29.8 & 34.1 & 43.2 & 71.1 & 99.8 & 106.6 & $110.2 \mathrm{de}$ \\
Blue lupin & 18.0 & 22.2 & 32.4 & 54.1 & 75.2 & 100.7 & 102.8 & $104.6 \mathrm{de}$ \\
Yellow lupin & 13.8 & 25.5 & 33.0 & 46.4 & 59.7 & 87.2 & 92.0 & 95.9 \\
\hline
\end{tabular}

Values in the same columns followed by different letters are significantly different $(P<0.05)$. 


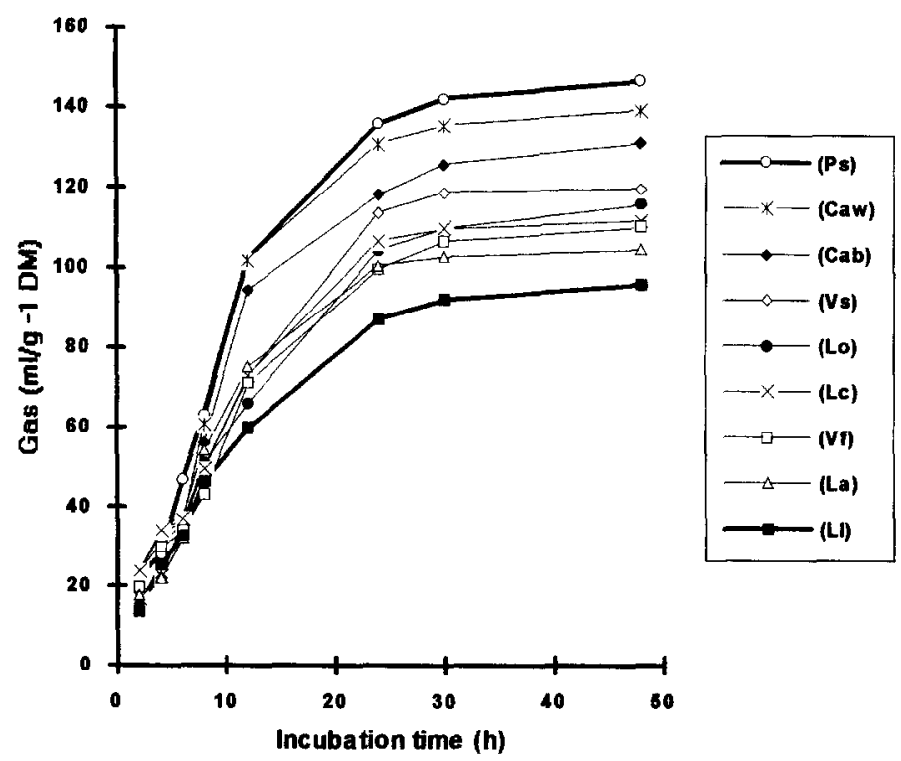

Fig. 1. Evolution of gas production for different legume grains.

DE was slightly different between grains (16.1-17.6 $\left.\mathrm{MJ} \mathrm{kg}^{-1} \mathrm{DM}\right)$ influenced probably by the levels of fat (EE) and fibre (NDF, WICW) in these feeds.

\subsection{Gas production}

Table 3 shows gas production for different grains under different periods of incubation. The data obtained 24,30 and $48 \mathrm{~h}$ apart from ( $\mathrm{Lo}$ ) did not show significant differences between themselves.

However, during the first hours of incubation ( 2 and $4 \mathrm{~h}$ ) the values observed were somewhat overlapping, making comparison difficult (Fig. 1).

At $48 \mathrm{~h}$, gas production varied between 95.9 and $146.7 \mathrm{ml} \mathrm{g}^{-1} \mathrm{DM}$, the lower value being for $(L l)$ and the higher for $(P s)$.

\section{Discussion}

\subsection{Chemical composition}

Starch values showed negative correlations with $C P$ values $(P<0.001)$ and in a lesser extent (not significant) with EE values. This may be the result of the substitution of starch for fat as energy stored in legume grains. In fact Daveby and Aman (1993) showed that in these feeds the major components are $\mathrm{CP}$, starch and/or crude fat.

Values of ADF/NDF $\leq 0.55$ were found in $(C a w),(V s),(L c)$ and $(L o)$ whereas those in lupinus were $\geq 0.85$. This is a consequence of the high hemicelluloses content of the cell walls in lupinus. 
$\mathrm{ADL} / \mathrm{NDF}$ values of 0.12 or higher were obtained in chick peas and in $(\mathrm{Vf})$, but values of 0.04 or below were obtained only with $(V s),\left(L_{0}\right)$ and $(L c)$. This is a consequence of the differences between grains according to lignin (ADL) levels. Values of 0.72 and 0.09 were observed by Bruno-Soares et al. (1996) in the lupinus $(L l)$ for the ratios $\mathrm{ADF} / \mathrm{NDF}$ and $\mathrm{ADL} / \mathrm{NDF}$, respectively.

The importance of the WICW, in legume grains, derives from the presence of significant amounts of pectic substances in theses grains (Carré and Brillouet, 1986), in particular in lupinus (Table 1). As it is known, these substances are not included in NDF fraction although being part of the plant cell walls (Van Soest, 1982).

\subsection{Gas production}

Gas production in the first hours of incubation does not allow the discrimination of the legume grains, as shown in Fig. 1. However, negative correlations could be observed with ADL, possibly through the adverse effects of lignin on microbial activity fermentation (Van Soest, 1982; Jung and Fahey, 1983), particularly in the initial phases of fermentation. In fact, during the first hours of incubation, ADL alone explains about $62 \%$ of the variation in gas production $(Y=25.5-3.5 \mathrm{ADL} ; P<0.01)$.

In the final stage of incubation at $48 \mathrm{~h}$, NDF becomes the best single predictor of gas production ( $\left.Y=175.7-2.8 \mathrm{NDF} ; r^{2}=0.84 ; P<0.001\right)$. Pell and Schofield (1993) observed that the degradation of NDF was directly related with the increase of gas production after the first hours of incubation.

The correlations between gas production $(48 \mathrm{~h})$ and DE, although positive, were not significant, which reflects, in these feeds, the importance of GE in determining the DE.

Positive but weak correlations were, however found between gas production and the OMD $(r=0.69 ; P<0.05)$, possibly due to the variation in the organic matter composition of these feeds.

The negative correlations between gas production $(48 \mathrm{~h})$ and $\mathrm{CP}(P<0.05)$, NDF $(P<0.001)$ and ADF $(P<0.01)$ may be a result of the reduction of microbial activity, from increasingly adverse environmental conditions as incubation time progresses. The antinutrient substances (ANF) present in these feeds may also contribute to the reduction of the microbial activity (Wood and Plumb, 1995).

The positive correlation found between gas production at $48 \mathrm{~h}$ and starch $(P<0.05)$, may be a consequence of its easy degradation.

\subsection{Organic matter digestibility}

The differences in OMD of legume grains reflect differences in their chemical composition namely in relation to levels of $\mathrm{CP}(P<0.001)$, ADF $(P<0.001)$ and starch $(P<0.001)$, with lupinus showing significantly lower values. The presence of ANF substances also may affect the OMD of these feeds (Duffus and Duffus, 1991; Saini et al., 1993).

The variation of the OMD may be explained in $86 \%$ by the $\mathrm{CP}(\mathrm{OMD}=103.4-0.57$ $\mathrm{CP})$ and in $87 \%$ by the starch content (OMD $=84.8+0.15 \mathrm{starch}$ ).

Otherwise, gas production ( $48 \mathrm{~h}$ ) only explains about $40 \%$ of the total OMD variation, which is very few if compared with the values given by Menke and Steingass 
(1988) for concentrate feeds (about 72\%). As suggested by Menke and Steingass (1988), the estimation of OMD is improved when the CP $\left(r^{2}=0.83\right)$ or the starch content $\left(r^{2}=0.85\right)$ is added to the volume of gas production in $48 \mathrm{~h}$ (OMD $=103.7-0.0018$ gas $-0.58 \mathrm{CP} ; P \leq 0.001$ and $\mathrm{OMD}=83.9+0.0087$ gas +0.14 starch; $P \leq 0.001$, respectively).

\section{Conclusions}

Gas production in itself was therefore not enough to assess OMD of legume grains. The variables of chemical composition, namely $\mathrm{CP}, \mathrm{ADF}$ and starch, were shown to be the best single predictors of OMD.

The accuracy of the estimates of OMD was not improved with the inclusion of the gas production in multiple regression equations based on chemical parameters.

\section{Acknowledgements}

The authors wish to thank Estação Nacional de Melhoramento de Plantas (ENMP), for the supply of the studied grains in this work. Financial assistance was provided by Commission of the European Communities under contract no. 8001-CT 91-0307.

\section{References}

Abreu, J.M.F., Freire, J.P.B., Cunha, L.F., 1992. The use of Lathyrus cicera in the diet of growing rabbits. In: I Jornadas tecnicas sobre leguminosas de grano. Univ. Valladolid, Palencia, Spain, pp. 261-267.

Association of Official Analytical Chemists, 1980. Official Methods of Analysis, 13th edn. AOAC, Washington, DC.

Bruno-Soares, A.M., Campos-Andrada, M.P. and Cunha, L.F., 1996. An evaluation of the chemical composition and degradability in rumen of a new Portuguese Lupinus luteus L. candivar. In: Abstract Book, Looking Toward the 21st Century. Eighth International Lupin Conference, Pacific Grove, Califomia, USA.

Carré, B., Brillouet, J.M., 1986. Yield and composition of cell wall residues isolated from various feedstuffs use for non-ruminant farm animals. J. Sci. Food Agric. 37, 314-351.

Carré, B., Brillouet, J.M., 1989. Determination of water insoluble cell walls in feeds. J. Assoc. Anal. Chem. 72, 463-467.

Castanon, J.I., Perez-Lanzac, J., 1990. Substitution of fixed amounts of soyabean meal for field beans (Vicia $f a b a$ ), sweet lupin (Lupinus albus), cull peas (Pisum sativum) and vetchs (Vicia sativa) in diets for high performance laying Leghorn hens. Brit. Poultry Sci. 31, 173-180.

Chominot, A., 1992. Les proteagineux dans l'economie europeenne des grandes cultures. In: L'Association Europeenne des Proteagineux (Eds.), Proc. 1st European Conference in Grain Legumes. Angers, France, pp. 529-538.

Cubero, J.I., 1983. Origen, evolucion y mejora genética de las leguminosas-grano. In: Cubero, J.I., Moreno, M.T. (Eds.), Leguminosas para Grano, MundiPrensa, Madrid, Espana.

Daveby, Y.D., Aman, P., 1993. Chemical composition of certain dehulled legume seeds and their hulls with special reference to carbohydrates. Swed. J. Agric. Res. 23, 133-139.

Duffus, C.M., Duffus, J.H., 1991. Introduction and overview. In: D’Mello, J.P., Duffus, C.M., Duffus, J.H. (Eds.), Toxic Substances in Crop Plants. The Royal Society of Chemistry, Cambridge, UK, pp. 1 20.

Duncan, D.B., 1955. Multiple range and multiple $F$-tests. Biometrics 11, 1-42. 
Elkowicz, K., Sosulski, F., 1982. Antinutritive factors in eleven legumes and their air-classified protein and starch fractions. J. Food Sci. 47, 1301-1304.

Frutos, P., Mantecon, A.R., Revesado, P.R., Gonzalez, J.S., 1995. Body fat depots and body condition score relationship: a comparison of two Spanish sheep breeds (Churra vs. Merina). In: CIHEAM (Centre International de Hautes Etudes Agronomiques Méditerranéennes) FAO (Organisation des Nations Unies pour Alimentation et l'Agriculture) (Eds.), Proceedings of the Seminar of the Working Group on Body Conditon of Sheep and Goats of the FAO/CIHEAM Network on Sheep and Goats. Zaragoza, Spain, pp. 19-23.

Hadjipanayiotou, M., Economides, S., Koumas, A., 1985. Chemical composition, digestibility and energy content of leguminous grains and straws grown in Mediterranean region Ann Zootechnie 34 (1), 23-30

Holl, F.B., Vose, J.R., 1980. Carbohydrate and protein accumulation in the developing field pea seed. Can. J Plant Sci, 60, 1109-1114.

Institut National de la Recherche Agronomique (INRA), 1984. L'alimentation des animaux monogastriques: porc, lapim, volailles. INRA, 7800 Versailles, Paris, $282 \mathrm{pp.}$

Institut National de la Recherche Agronomique (INRA), 1988. Alimentation des bovins, ovins and caprins INRA, 7800 Versailles, Paris, $470 \mathrm{pp}$.

Jefferies, B.C., 1961. Body condition scoring and its use in management. Tasmanian J. Agr. 32, 19-21.

Jung, H.G., Fahey, G.R., 1983. Nutritional implications of phenolic monomers and lignin: A review. J. Anim. Sci. 57, 206.

Lloyd, L.E., McDonald, B.E., Crampton, E.W., 1978. Coefficients of apparent digestibility. In: Freeman and Company (Eds.), Fundamentals of Nutrition. San Francisco, USA.

Ministerio de Agricultura Pesca y alimentacion (MAPA) e Asociacion de Investigacion para el estudio de Nuevas fuentes Proteicas y Energeticas para la Alimentacion Animal (AINPORT) 1984. Tablas de composicion de primeras materias para nutrición animal. DGPA e GEFPC, Madrid, Espana, $310 \mathrm{pp}$.

Menke, K.H., Raab, L., Salewwski, A., Steingass, H., Fritz, D., Schneider, W., 1979. The estimation of the digestibility and metabolizable energy content of ruminant feedingstuffs from the gas production when they are incubated with rumen liquor in vitro. J. Agric. Sci. Camb. 93, 217-222.

Menke, K.H., Steingass, H., 1988. Estimation of the energetic feed value obtained from chemical analysis and in vitro gas production using rumen fluid. In: Members of German Universitics and Rescarch Institutions by the Institute for Scientific Co-operation (Eds.), Animal Research and Development. Volume 28, $55 \mathrm{pp}$.

NP, 1986. Norma portuguesa no. 1785. 1a Directiva. CEE no71/250/CEE/Comissão de 15 Junho de 1971 .

Pell, A.N., Schofield, P., 1993. Nutrition, feeding, and calves. Computerized monitoring of gas production to measure forage digestion in vitro. J. Dairy Sci. 76, 1063-1073.

Robertson, J.B., Van Soest, P.J., 1981. The detergent system of analysis and its application to human foods. In: James, W.P.T., Theander, O. (Eds.), The Analysis of Dietary Fiber in Food. Marcell Dekker, NY, pp. 123-157.

Todorov, N.A., 1988. Cereals, pulses and oilseeds. In: De Boer, F., Bickel, H. (Eds.), Livestock Production Science. Elsevier, Amsterdam, pp. 47-95.

Saini, H.S., Poel, A.F.B., Huisman, J., 1993. Distribution of tannins, vicine and convicine activity in legume seeds. In: van der Poel, A.F.B., Huisman, J. (Eds.), Recent Advances of Research in Antinutritional Factors in Legume Seeds. Wageningen Pers, Wageningen, Netherlands.

Thivend, P., Mercier, C.H., Guilbot, H., 1965. Dosage de l'amidon dans les milieux complexes. Ann. Biol. Anim. Bioch. Biophys. 5, 513-526.

Van Soest, P.J., 1982. Nutritional ecology of the ruminant. O\&B Books, Corvallis, USA, $374 \mathrm{pp}$.

Wiseman, J., Cole, D.J., 1988. European legumes in diets for non ruminants. In: Haresi, W., Cole, Cole (Eds.), Recent Advances in Animal Nutrition. Butterworths, London.

Wood, C.D., Plumb, V.E., 1995. Evaluation of assays for phenolic compounds on the basis of in vitro gas production by rumen microorganisms. Anim. Feed Sci. Technol. 56, 195-206. 